\title{
CURRENT MEDICAL STRATEGIES IN THE PREVENTION OF OVARIAN HYPERSTIMULATION SYNDROME
}

\author{
Miro Kasum ${ }^{1}$, Slavko Orešković ${ }^{1}$, Daniela Franulić ${ }^{1}$, Ermin Čehić \\ Albert Lila ${ }^{3}$, Goran Vujić ${ }^{1}$ and Franjo Grgić ${ }^{1}$ \\ ${ }^{1}$ Clinical Department of Obstetrics and Gynecology, Zagreb University Hospital Center, School of Medicine, \\ University of Zagreb, Zagreb, Croatia; ${ }^{2}$ Zenica Cantonal Hospital, Zenica, Bosnia and Herzegovina; \\ ${ }^{3}$ Kosovo Occupational Health Institute, Giakove, Kosovo
}

\begin{abstract}
SUMMARY - The purpose of this review is to analyze current medical strategies in the prevention of ovarian hyperstimulation syndrome (OHSS) during ovarian stimulation for in vitro fertilization. Owing to contemporary preventive measures of OHSS, the incidence of moderate and severe forms of the syndrome varies between $0.18 \%$ and $1.40 \%$. Although none of medical strategies is completely effective, there is high-quality evidence that replacing human chorionic gonadotropin (hCG) by gonadotropin-releasing hormone $(\mathrm{GnRH})$ agonists after $\mathrm{GnRH}$ antagonists and moderate-quality evidence that $\mathrm{GnRH}$ antagonist protocols, dopamine agonists and mild protocols reduce the occurrence of OHSS. Among various $\mathrm{GnRH}$ agonists, buserelin $0.5 \mathrm{mg}$, triptorelin $0.2 \mathrm{mg}$ and leuprolide acetate $(0.5-4 \mathrm{mg})$ have been mostly utilized. Although $\mathrm{GnRH}$ trigger is currently regarded as the best tool for OHSS prevention, intensive luteal support with exogenous administration of estradiol and progesterone or low-dose hCG on the day of oocyte retrieval or on the day of $\mathrm{GnRH}$ agonist trigger are required to achieve optimal conception rates due to early luteolysis. Among currently available dopamine agonists, cabergoline, quinagolide and bromocriptine are the most common drugs that should be used for prevention of both early and late OHSS. Mild stimulation protocols offer attractive option in OHSS prevention with satisfactory pregnancy rates.
\end{abstract}

Key words: Ovarian hyperstimulation syndrome - prevention and control

\section{Introduction}

Ovarian hyperstimulation syndrome (OHSS) is the most serious iatrogenic complication of controlled ovarian stimulation (COS), which can vary from mild illness to severe, potentially life-threatening disease. The syndrome almost always occurs a few days after receiving human chorionic gonadotropin (hCG) (early OHSS), or later (late OHSS), which depends on the occurrence of endogenous hCG ${ }^{1}$. Although OHSS

Correspondence to: Prof. Miro Kasum, $M D$, PhD, Clinical Department of Obstetrics and Gynecology, Zagreb University Hospital Center, Petrova 13, HR-10000 Zagreb, Croatia

E-mail: mkasum@gmail.com

Received February 12, 2016, accepted April 5, 2016 may occasionally occur spontaneously between eight and twelve weeks of pregnancy or with a follicle-stimulating hormone ( $\mathrm{FSH}$ ) producing pituitary adenoma, the great majority of cases are iatrogenic due to ovulation induction in women undergoing assisted reproductive techniques (ART) ${ }^{2}$. According to the latest European Society of Human Reproduction and Embryology (ESHRE) report, the incidence of OHSS ranges from $0.18 \%$ to $1.40 \%$ of stimulated in vitro fertilization (IVF) cycles in European countries ${ }^{3}$. Although the pathophysiology of the syndrome is not entirely clear, it is assumed that the vasoactive substances secreted by ovaries under hCG stimulation may play a key role in increasing capillary permeability observed in OHSS. Of all the different vasoactive cy- 
tokines, vascular endothelial growth factor (VEGF) is the principal mediator and is most responsible for vascular hyperpermeability. A generalized capillary leak and acute shift of protein-rich fluid from the intravascular compartment into the third space may lead to hypoproteinemia, oliguria, acute renal failure and increased blood viscosity with changes in coagulation parameters resulting in severe morbidity and possible mortality due to thromboembolic events ${ }^{4}$.

Therefore, good preventive strategies may be required, which would enable a fair chance to achieve safe pregnancy and to reduce or avoid the occurrence of the syndrome as a life-threatening complication of IVF treatment. Although various strategies have been proposed and have been tried to prevent this serious complication, none was found to be completely effective. The key to prevent OHSS is recognition of risk factors for the syndrome and the experience with ovulation stimulation. Primary prevention includes identification of patients at high risk of OHSS such as younger age, a history of good response to gonadotropins, thin women, polycystic ovary syndrome (PCOS) and history of allergies. Ovulation induction protocols should be individually tailored with minimal dose and duration of gonadotropins combined with gonadotropin-releasing hormone $(\mathrm{GnRH})$ antagonist or in vitro oocyte maturation, and carefully monitored. Secondary prevention represents all interventions for the early control of OHSS during ovulation induction including cycle cancellation, coasting, trigger ovulation by low doses of hCG or by alternative agents, cryopreservation of oocytes/embryos and adequate luteal phase support ${ }^{5,6}$. Current evidence demonstrates that age, antral follicle count and anti-müllerian hormone levels have proved as the best methods of predicting high ovarian response before starting COS. Although estradiol (E2) levels were previously less reliable in prediction of OHSS during ovulation stimulation ${ }^{7}$, currently E2 concentrations, the number of medium/large follicles on the day of hCG and the number of retrieved oocytes are regarded as reliable markers of high ovarian response ${ }^{8}$. There is high-quality evidence that replacing hCG by $\mathrm{GnRH}$ agonists and moderate-quality evidence that antagonist protocols, dopamine agonists and mild stimulation reduce the occurrence of OHSS. However, evidence for the effect of other interventions is of low/very low quality ${ }^{8}$. Accordingly, the objective of the present review is to analyze the effectiveness and safety of medical strategies that currently may be justifiably utilized in the prevention of OHSS.

\section{GnRH Agonists}

Gonadotropin-releasing hormone agonists trigger instead of hCG in the context of OHSS prevention has been used for $>25$ years. In its first decade, it did not gain popularity because it cannot work in $\mathrm{GnRH}$ agonist-based ovarian stimulation protocols. Although $\mathrm{GnRH}$ agonist initially binds and activates $\mathrm{GnRH}-$ receptors inducing a transient rise in gonadotropins, known as a flare-up, this is followed by a state of pituitary desensitization, resulting in a decrease in $\mathrm{GnRH}$ receptors and diminished response to $\mathrm{GnRH}$ stimulation. However, the GnRH antagonist occupies the $\mathrm{GnRH}$ receptor competitively without causing downregulation. The antagonistic effects of $\mathrm{GnRH}$ antagonists may be overcome by $\mathrm{GnRH}$ agonists, as $\mathrm{GnRH}$ agonists have a greater affinity for the $\mathrm{GnRH}$ receptor than $\mathrm{GnRH}$ antagonists. By injecting a single bolus of $\mathrm{GnRH}$ agonist, the antagonist is displaced from the receptor by the $\mathrm{GnRH}$ agonist, which activates the receptor, inducing a flare-up of gonadotropins that accumulate during $\mathrm{GnRH}$ antagonist protocols and effectively stimulating the final oocyte maturation and ovulation $^{9-11}$. Although a single bolus of hCG at midcycle has been the gold standard for triggering final oocyte maturation and ovulation in ART cycles, it seems that the $\mathrm{GnRH}$ agonist trigger may allow a more physiological surge of both luteinzing hormone (LH) and FSH. The short duration of the LH surge with the GnRH agonist trigger of approximately thirty-four hours has been shown to be beneficial for preventing OHSS in GnRH antagonist IVF cycles, when compared with the prolonged elevation of hCG $(\geq 6$ days) after exposure to an hCG bolus ${ }^{12}$. Although an advantage of the $\mathrm{GnRH}$ agonist trigger is the ability to retrieve oocytes in high responders with a markedly reduced risk of OHSS, the induction of early luteolysis after the $\mathrm{GnRH}$ agonist trigger represents a problem that requires the use of aggressive steroidal luteal support or low-dose hCG to allow successful fresh embryo transfer (ET) and live birth. Early luteolysis following COS and GnRH agonist is likely due to supraphysiological steroid hormone concentrations inhibiting the LH secretion via negative feedback at the level of the hypothalamic-pituitary-gonadal axis and short- 
er duration of the endogenously induced LH surge with a potential weaker activation of the $\mathrm{LH} / \mathrm{hCG}$ receptor ${ }^{13}$.

Although different $\mathrm{GnRH}$ agonists have been used in $\mathrm{GnRH}$ antagonist cycles for the final oocyte maturation in high-responders, no universal consensus has been defined regarding the optimal agonist kind and dose, and there is no report evaluating the impact of different agonists on cycle outcomes. Among various $\mathrm{GnRH}$ agonists, buserelin $0.5 \mathrm{mg}^{14}$, triptorelin 0.2 $\mathrm{mg}^{15,16}$ and leuprolide acetate $(0.5-4 \mathrm{mg})^{17,18}$ have been utilized and almost all studies compared the outcomes of $\mathrm{GnRH}$ agonist triggered cycles with the cycles triggered with hCG. Most previous studies have reported successful oocyte maturation with $0.2-0.3 \mathrm{mg}$ triptorelin, $0.5 \mathrm{mg}$ buserelin and $1 \mathrm{mg}$ leuprolide acetate $^{14-16,19}$. Since there is no established triggering dose, $\mathrm{GnRH}$ agonists may be effective even at lower doses because $0.1 \mathrm{mg}$ triptorelin effectively induces final oocyte maturation in IVF cycles similarly as standard doses. The rate of retrieved oocytes per follicle (89\%) and fertilization rate (71\%) support the use of lower doses of $\mathrm{GnRH}$ agonists in clinical practice ${ }^{16}$. Although higher doses of agonists for the final oocyte maturation have a potential to result in higher gonadotropin surge amplitude and improve the oocyte quantity, the mean number of retrieved oocytes varies and no clear benefit has been demonstrated by this approach $^{18}$.

Since the possible standardization for $\mathrm{GnRH}$ agonist trigger criteria that will yield optimal outcomes have not yet been established, some authors used increased estradiol levels as a criterion ${ }^{20}$, whereas others assessed only excess number of available follicles during the late follicular phase of ovarian stimulation ${ }^{21}$. The criteria for $\mathrm{GnRH}$ agonist triggering for the patients at high risk of OHSS characterized by a high number of follicles ( $>12)$ measuring $\geq 12 \mathrm{~mm}$ and/or high serum E2 levels ( $\geq 4000 \mathrm{pg} / \mathrm{mL}$ ) have been suggested $^{18}$. According to results from several studies in the last decade in OHSS high risk patients, the GnRH agonist for ovulation triggering significantly reduces or almost eliminates the incidence of OHSS and therefore $\mathrm{GnRH}$ agonist trigger is the best tool for OHSS prevention ${ }^{3,22-24}$. GnRH agonist triggering is a valid alternative to hCG triggering, resulting in elimination of OHSS and no other prevention strategy comes close to this result $\mathrm{t}^{25}$. However, several anecdotal cases of severe OHSS, even after GnRH agonist triggering combined with freezing all embryos in $\mathrm{GnRH}$ antagonist cycles have been published and in these cases of extreme hyper-responders other prevention strategies should be considered ${ }^{26,27}$. Therefore, clinicians should be aware that severe early OHSS could rarely occur even after $\mathrm{GnRH}$ agonist trigger instead of hCG, despite the fact that induction of final oocyte maturation with $\mathrm{GnRH}$ agonist significantly reduces the risk of OHSS. Moreover, an additional risk of late OHSS is possible if pregnancy occurs ${ }^{28}$. Despite acceptable cycle parameters following agonist-triggered cycles, a recently updated Cochrane review has reported that the use of $\mathrm{GnRH}$ agonist trigger instead of hCG in fresh autologous cycles was associated with a lower live birth rate, lower ongoing pregnancy rate and higher rate of early miscarriage. However, in donorrecipient cycles, the use of $\mathrm{GnRH}$ agonists resulted in a lower incidence of OHSS, with no evidence of difference in live birth rate. Therefore, GnRH agonist could be useful for women who choose to avoid fresh transfers, women who donate oocytes to recipients, or women who wish to freeze their eggs for later use in the context of fertility preservation ${ }^{29}$. Unfortunately, data from studies in the review were not comparable due to different luteal phase protocols used; therefore, the analysis missed the fact that luteal support is the factor which affects pregnancy rate and not the use of $\mathrm{GnRH}$ agonist trigger for final oocyte maturation ${ }^{30}$. Therefore, a meaningful comparison between $\mathrm{GnRH}$ agonist and hCG trigger must be confined to outcome measures that are not affected by the luteal support used $^{31}$. Unfortunately, standard luteal phase support after $\mathrm{GnRH}$ agonist triggering has been reported to be associated with lower conception rates due to corpus luteum dysfunction. Aiming to attain an adequate luteal phase for a fresh embryo transfer and to improve IVF outcomes, the luteal phase support protocols after $\mathrm{GnRH}$ agonist trigger have emerged over recent years by using several different concepts. The American concept which relies mostly on intensive luteal support with aggressive exogenous administration of E2 and progesterone is effective in maintaining optimal conception rates in patients with peak E2 levels $>4000 \mathrm{pg} /$ $\mathrm{mL}$. The European approach promotes the production of endogenous steroids by the corpus luteum via exogenous supplementation of a small dose of hCG on the day of oocyte retrieval or on the day of $\mathrm{GnRH}$ agonist 
trigger ('dual trigger'). However, patients with peak E2 levels $<4000 \mathrm{pg} / \mathrm{mL}$ may benefit from dual trigger with GnRH agonist and 1000 IU hCG with intensive luteal phase support to optimize conception rates while still avoiding significant $\mathrm{OHSS}^{32,33}$. In patients at risk to develop severe OHSS with less than 20 oocytes retrieved following the ultra-short flare GnRH agonist/GnRH antagonist protocol, $\mathrm{GnRH}$ agonist trigger has been offered recently with an intensive luteal support and $1500 \mathrm{IU}$ of hCG in order to improve IVF outcome while eliminating $\mathrm{OHSS}^{34}$.

Although the induction of final follicular maturation using $\mathrm{GnRH}$ agonist with its advantages over hCG trigger represents a paradigm shift in the ovulation triggering concept in ART, kisspeptins have also been shown to effectively elicit an LH surge, which suggests a completely new, 'natural' pharmacological option and as a new trigger concept ${ }^{35}$. It seems that the risk of OHSS development may be even more decreased following kispeptin trigger comparing to $\mathrm{GnRH}$ agonist, but it is highly speculative because no study so far has been performed in an OHSS risk population and therefore its safety and efficacy remains to be determined ${ }^{3}$.

\section{GnRH Antagonist Protocols}

Gonadotropin-releasing hormone antagonists directly and rapidly inhibit gonadotropin release during COS within several hours without hypo-estrogenic side effects, flare-up or long down-regulation and higher OHSS incidence as compared to GnRH agonists. Three different protocol regimens have been used including multiple-dose fixed $(0.25 \mathrm{mg}$ daily from day six or seven of COS) or flexible $(0.25 \mathrm{mg}$ daily when leading follicle is 14 to $15 \mathrm{~mm}$ ) and single-dose regimen ( $3 \mathrm{mg}$ on day 7 to 8 of stimulation) protocols, with or without the addition of an oral contraceptive pill. Although the probability of clinical pregnancy with $\mathrm{GnRH}$ antagonists initially seemed lower than with $\mathrm{GnRH}$ agonists, more recent studies were unable to provide any evidence for a difference in the live birth rates by using $\mathrm{GnRH}$ antagonists as compared to long $\mathrm{GnRH}$ agonist protocols. According to an update of a Cochrane review and forty-five RCTs, the use of $\mathrm{GnRH}$ antagonist compared with long $\mathrm{GnRH}$ agonist protocols was associated with a significantly lower incidence of OHSS and there was no evidence for a dif- ference in live birth rates ${ }^{36-38}$. Comparing the effectiveness and safety of $\mathrm{GnRH}$ antagonist and $\mathrm{GnRH}$ agonist long protocol in supposedly normal ovarian responders undergoing IVF, results of a recent meta-analysis show that the number of stimulation days, gonadotropin amount, E2 value on the day of hCG, number of oocytes retrieved and incidence of OHSS were significantly lower with the $\mathrm{GnRH}$ antagonist protocol, whereas the ongoing pregnancy and live birth rates were similar in the two groups ${ }^{39}$. Evaluating the outcomes of IVF utilization of GnRH antagonists for ovarian stimulation in PCOS patients compared with long agonist protocols, the clinical pregnancy rate was similar in the two groups, whereas for severe OHSS, a GnRH antagonist protocol was significantly better in PCOS patients ${ }^{40,41}$.

\section{Dopamine Agonists}

In a rat ovarian hyperstimulation model, it was demonstrated that low-dose dopamine agonist administration blocked VEGF-mediated vascular hyperpermeability without altering VEGF receptor(r) 2-dependent luteal angiogenesis ${ }^{42}$. Targeting the VEGF/ VEGFR2 pathway by the administration of pharmacotherapy through low doses of dopamine agonists might be the most appropriate way to prevent OHSS in high-risk patients. The proposed mode of action appears to be through partial blockage of VEGFR2 specific phosphorylation sites involved in the development of vascular permeability without affecting tyrosine sites or activating angiogenic activity ${ }^{43}$. It is likely that decreased VEGF secretion leads to less VEGFR2 activation and lower amounts of phosphorylated VEGFR2 resulting in inhibition of increased vascular permeability and OHSS prevention ${ }^{44}$.

According to guidelines for the use of dopamine agonist, its use should be considered in patients at high risk of OHSS by the presence with one or more of the following findings: $>20$ growing follicles of more than $12 \mathrm{~mm}$ in diameter; $\mathrm{E} 2>3000 \mathrm{pg} / \mathrm{mL}$; and in patients with a history of previous OHSS even without evident signs of high ovarian response. It would be preferable to start with the treatment a few hours before the injection of hCG, to enable the presence of dopamine agonists before the rise in VEGF production. Cabergoline is currently used at a daily dose of $0.5 \mathrm{mg}$ for eight days despite its long half-life (65-69 h) because 
it is the best known effective regimen with good tolerability, in addition to rectal bromocriptine at a daily dose of $2.5 \mathrm{mg}$ for sixteen days as an alternative ${ }^{45}$. In hyperstimulated women undergoing ART, cabergoline successfully reduces hemoconcentration and ascites as a well-established and safe medication in the prevention of $\mathrm{OHSS}^{46}$. Although cabergoline is probably not as effective as replacing hCG with a $\mathrm{GnRH}$ agonist for decreasing the incidence of OHSS, it can be used as a secondary prevention measure for women at high risk of OHSS undergoing ART and it appears to reduce the risk of the syndrome, especially moderate OHSS. In addition, cabergoline reduces the occurrence of moderate-severe OHSS with no relevant negative effects on the number of retrieved oocytes or implantation rates and clinical pregnancy, without deleterious impact on pregnancy outcome $e^{47,48}$. Moreover, evaluating the long-term effects of prophylactic treatment with cabergoline, no negative impact on live birth rates and miscarriage rates without increased rate of congenital malformations of the babies born has been observed $^{49,50}$.

Quinagolide used in a fixed regimen of three oral doses $(50,100$ and $200 \mu \mathrm{g} /$ day), starting on the day of hCG and continued for 17-21 days, significantly reduces the frequency of moderate/severe early OHSS ( $12 \%$ vs. $13 \%$ vs. $4 \%$ ) as compared with placebo (23\%), without compromising pregnancy or treatment outcome. Although the $200-\mu \mathrm{g}$ dose of quinagolide was most effective in preventing moderate/severe early OHSS in IVF patients, this dose was associated with poor tolerability when administered without dose titration, but also lower doses of quinagolide may be efficacious. The treatment effect is more marked in patients that did not achieve clinical pregnancy and therefore it may be more suitable for oocyte donors or for patients with postponed embryo transfer. However, if quinagolide is used at high doses without dose titration, it is associated with poor tolerability, although the incidence of deleterious events declines after the initial days of treatment ${ }^{51}$.

Bromocriptine is the next dopamine agonist after cabergoline which evokes interest in recent years, owing to its advantages in patients at risk of OHSS, including its shorter half-life and greater experience with this drug in pregnancy, the lack of teratogenicity, despite side effects such as nausea, headaches and orthostatic dysregulation. The incidence of clinically sig- nificant OHSS was significantly lower (17.5\%) as compared to controls (40.9\%) due to the beneficial effect of bromocriptine $2.5 \mathrm{mg}$ for rectal insertion, starting on the day of ovum pick up for a period of sixteen days, with no differences between the groups in clinical pregnancy rates ${ }^{52}$.

Although according to a recent meta-analysis the use of dopamine agonists appears to be useful for the prevention, but less effective for the treatment of OHSS, yet so far, no conclusions can be made as for when to start and stop treatment, the most effective drug, the optimal dose, or the most appropriate drug regimen ${ }^{53}$. However, in the light of the new pathogenic and pharmacological evidence, currently dopamine agonists should definitely be considered for prevention of both early and late OHSS. Future prospective randomized studies should compare different modalities in women at high risk of $\mathrm{OHSS}^{54}$.

\section{Mild Stimulation Protocols}

Mild ovarian stimulation for IVF uses a low dosage of gonadotropins (100-150 IU), which usually starts in the early follicular phase in combination with a $\mathrm{GnRH}$ antagonist five to seven days of stimulation to produce a maximum of ten oocytes. However, minimal stimulation refers to the use of a sequential administration of clomiphene citrate (CC) followed by low-dose gonadotropins and a $\mathrm{GnRH}$ antagonist that yields a maximum of five oocytes, with a range from one to five. Both stimulations offer an attractive option to reduce the incidence of OHSS in patients who have experienced this complication in a previous treatment cycle or in high-responders ${ }^{55}$. However, there is only moderate-quality evidence that mild stimulation reduces OHSS without producing a clinically relevant difference in clinical pregnancy rates ${ }^{8}$. Since recently, scientific interest has been increasingly focused on mild approaches for ovarian stimulation in clinical practice because mild stimulations are more physiological, aiming to develop safer and more patientfriendly protocols, less drug use, lower costs and decreased risks of treatment, especially OHSS. A lower incidence of OHSS (4.7\%) was observed in patients with a mild/minimal stimulation protocol of recombinant FSH combined with GnRH antagonist than in patients with a standard long protocol (8.4\%). Although a significantly higher pregnancy rate $(37.7 \%$ 
vs. $23.4 \%)$ and delivery rate (32.8\% vs. $20.1 \%)$ were observed in favor of patients with mild stimulation compared to conventional long down-regulation regimen, these data are not evidence based ${ }^{56}$. Comparing the effectiveness of mild ovarian stimulation with GnRH-antagonist and long protocol with low-dose FSH in young, normo-ovulatory responders undergoing IVF, the incidence of severe OHSS, as well as pregnancy and implantation rates were comparable with the two regimens ${ }^{57}$. Furthermore, there was no evidence indicating that minimal stimulation regimens differed significantly from gonadotropins in $\mathrm{GnRH}$ agonist protocols in terms of OHSS incidence and live births or pregnancy rates. According to findings from a Cochrane analysis, the use of $\mathrm{CC}$ with gonadotropins (with or without mid-cycle antagonist) led to a reduction in the incidence of OHSS varying between $0.8 \%$ and $1.8 \%$, compared with $3.5 \%$ preva-

Table 1. Characteristics of current medical strategies in the prevention of ovarian hyperstimulation syndrome

\begin{tabular}{|c|c|c|c|c|}
\hline $\begin{array}{l}\text { Medical strategies } \\
\text { /characteristics }\end{array}$ & Studies & Advantages & Disadvantages & $\begin{array}{l}\text { Quality } \\
\text { of evidence }\end{array}$ \\
\hline $\begin{array}{l}\text { GnRH agonist trigger } \\
\text { - buserelin } 0.5 \mathrm{mg} \\
\text { - triptorelin } 0.2 \mathrm{mg} \\
\text { - leuprolide acetate } \\
0.5-4 \mathrm{mg}\end{array}$ & $\begin{array}{l}\text { Thomsen } \text { et al. }{ }^{3} \\
\text { Casper et al. }{ }^{12} \\
\text { Engmann } \text { et al. }{ }^{14} \\
\text { Gülekli et al. }{ }^{16} \\
\text { Humaidan } \text { et al. } .^{21} \\
\text { Griesenger } \text { et al. }{ }^{22} \\
\text { Fatemi } \text { et } a l .{ }^{26}\end{array}$ & $\begin{array}{l}\text { Short duration } \\
\text { of LH surge ( } 34 \text { hours) } \\
\text { Reduced or almost } \\
\text { eliminated OHSS } \\
\text { Best tool for OHSS } \\
\text { prevention } \\
\text { Satisfactory pregnancy } \\
\text { rate in fresh cycles with } \\
\text { intensive luteal steroidal } \\
\text { support or low-dose hCG }\end{array}$ & $\begin{array}{l}\text { Early luteolysis } \\
\text { Embryocryopreservation } \\
\text { or ET in fresh cycle with } \\
\text { aggressive luteal steroidal } \\
\text { support or low-dose hCG } \\
\text { Several cases of OHSS } \\
\text { despite } \\
\text { embryocryopreservation } \\
\text { Risk of late OHSS with } \\
\text { pregnancy }\end{array}$ & High \\
\hline $\begin{array}{l}\text { GnRH antagonist } \\
\text { regimens } \\
\text { - single } 0.3 \mathrm{mg} \\
\text { - multiple } 0.25 \mathrm{mg} \\
\text { - fixed } \\
\text { - flexible }\end{array}$ & $\begin{array}{l}\text { Al-Inany et } a l .{ }^{37} \\
\text { Giliam }{ }^{38} \\
\text { Xiao et al. }{ }^{39} \\
\text { Lin et al. }{ }^{40} \\
\text { Xiaou et al. }{ }^{41}\end{array}$ & $\begin{array}{l}\text { Lower number of } \\
\text { stimulation days, } \\
\text { gonadotropin doses } \\
\text { and estradiol levels } \\
\text { Lower incidence } \\
\text { of OHSS } \\
\text { No difference in live-birth } \\
\text { rates comparing with } \\
\text { GnRH agonist protocols }\end{array}$ & $\begin{array}{l}\text { Lower number of oocytes } \\
\text { retrieved }\end{array}$ & Moderate \\
\hline $\begin{array}{l}\text { Dopamine agonists } \\
\text { - cabergoline } 0.5 \mathrm{mg} \\
\text { - quinagolide } 200 \mathrm{mcg} \\
\text { - bromocriptine } 2.5 \mathrm{mg}\end{array}$ & $\begin{array}{l}\text { Soares }^{45} \\
\text { Tang et al. } \\
\text { Leitao et al. }{ }^{48} \\
\text { Youssef et al. }{ }^{49} \\
\text { Alvarez et al. } \\
\text { Busso et al. } .^{51} \\
\text { Baumgarten } \text { et al. }{ }^{53}\end{array}$ & $\begin{array}{l}\text { Lower occurrence } \\
\text { of mild-severe OHSS } \\
\text { No negative effects } \\
\text { on the number oocytes } \\
\text { retrieved and pregnancy } \\
\text { outcome (miscarriage, } \\
\text { congenital malformations } \\
\text { and live-birth rate) }\end{array}$ & $\begin{array}{l}\text { Less effective for the } \\
\text { treatment of OHSS }\end{array}$ & Moderate \\
\hline $\begin{array}{l}\text { Mild stimulation } \\
\text { - lower doses } \\
\text { of gonadotropins } \\
\text { - CC with } \\
\text { gonadotropins }\end{array}$ & $\begin{array}{l}\text { Nastri et al. }{ }^{8} \\
\text { Zarek et al. }{ }^{55} \\
\text { Rinaldi et al. }{ }^{56} \\
\text { Casano et al. } .^{57} \\
\text { Gibrel et al. } .^{58} \\
\text { Figueiredo et al. }{ }^{59}\end{array}$ & $\begin{array}{l}\text { Mild ovarian response } \\
\text { Less drug use and lower } \\
\text { cost } \\
\text { Lower incidence } \\
\text { of OHSS } \\
\text { Satisfactory pregnancy } \\
\text { rates and pregnancy } \\
\text { outcome }\end{array}$ & $\begin{array}{l}\text { Higher risk of miscarriage } \\
\text { rates is correlated with } \\
\text { poor ovarian response } \\
\text { comparing to hyper- } \\
\text { response to ovarian } \\
\text { stimulation }\end{array}$ & Moderate \\
\hline
\end{tabular}

OHSS = ovarian hyperstimulation syndrome; $\mathrm{LH}=$ luteinizing hormone; $\mathrm{GnRH}=$ gonadotropin-releasing hormone; $\mathrm{ET}=\mathrm{embryo}$ transfer; $\mathrm{CC}=$ clomiphene citrate 
lence of OHSS using a GnRH agonist regimen ${ }^{58}$. It is likely that $\mathrm{CC}$ with gonadotropin and $\mathrm{GnRH}$ antagonist decreases the risk of OHSS because in a recent meta-analysis there was a significant reduction in OHSS $(0.5 \%)$ as compared with conventional controlled ovarian hyperstimulation $(4.1 \%)^{59}$ (Table 1$)$.

\section{Conclusion}

Although among currently available medical strategies none is completely effective, there is high-quality evidence that replacing hCG by $\mathrm{GnRH}$ agonists and moderate-quality evidence that antagonist protocols, dopamine agonists and protocols with a mild ovarian response reduce the occurrence of OHSS. GnRH agonist trigger is the best tool for OHSS prevention due to significant decrease in the incidence of OHSS, however, the use of intensive steroidal luteal support or low-dose hCG is required to achieve optimal conception rates. The incidence of OHSS was significantly lower in the $\mathrm{GnRH}$ antagonist protocol than in $\mathrm{GnRH}$ agonist long regimen, whereas live birth rates were similar in the two groups. Among dopamine agonists used, cabergoline, quinagolide and bromocriptine are the most common drugs that should be considered for OHSS prevention, especially for moderate forms of the syndrome, without adverse effects on pregnancy outcome. Furthermore, protocols with a mild ovarian response represent an attractive option to reduce the incidence of OHSS in patients who have experienced this complication in a previous treatment cycle or in high-responders with satisfactory pregnancy outcome.

\section{References}

1. Orvieto R. Ovarian hyperstimulation syndrome - an optimal solution for an unresolved enigma. J Ovarian Res. 2013;6:7782, doi: 10.1186/1757-2215-6-77

2. Kasum M, Orešković $\mathrm{S}$, Ježek D. Spontaneous ovarian hyperstimulation syndrome. Coll Antropol. 2013;37:653-6.

3. Thomsen L, Humaidan P. Ovarian hyperstimulation syndrome in the $21^{\text {st }}$ century: the role of gonadotropin-releasing hormone agonist trigger and kisspeptin. Curr Opin Obstet Gynecol. 2015;27:210-4, doi: 10.1097/GCO.0000000000000170

4. Soares SR, Gomez R, Simon C, García-Velasco JA, Pellicer A. Targeting the vascular endothelial growth factor system to prevent ovarian hyperstimulation syndrome. Hum Reprod Update. 2008;14:321-33, doi: 10.1093/humupd/dmn008
5. Soave I, Marci R. Ovarian stimulation in patients in risk of OHSS. Minerva Ginecol. 2014;66:165-78, doi: 10.4103/09741208.86080

6. Humaidan P, Quartarolo J, Papanikolaou EG. Preventing ovarian hyperstimulation syndrome: guidance for the clinician. Fertil Steril. 2010;94:389-400, doi: 10.1016/j.fertnstert.2010. 03.028

7. Papanikolaou EG, Pozzobon C, Kolibianakis EM, Camus M, Tournaye H, Fatemi HM, et al. Incidence and prediction of ovarian hyperstimulation syndrome in women undergoing gonadotropin-releasing hormone antagonist in vitro fertilization cycles. Fertil Steril, 2006;85:112-20.

8. Nastri CO, Teixeira DM, Moroni RM, Leitão VM, Martins WP. Ovarian hyperstimulation syndrome: pathophysiology, staging, prediction and prevention. Ultrasound Obstet Gynecol, 2015;45:377-93, doi: 10.1002/uog.14684

9. Kol S, Itskovitz-Eldor J. Gonadotropin-releasing hormone agonist trigger: the way to eliminate ovarian hyperstimulation syndrome - a 20-year experience. Semin Reprod Med. 2010; 28:500-5, doi: 10.1055/s-0030-1265677

10. Rabati BK, Zeidi SN. Investigation of pregnancy outcome and ovarian hyper stimulation syndrome prevention in agonist and antagonist gonadotropin-releasing hormone protocol. J Res Med Sci. 2012;17:1063-6.

11. Taylor JE, Miller BT, Gray KD, Scott RT Jr, Catherino WH, Segars JH. The mechanism responsible for the supraphysiologic gonadotropin surge in females treated with gonadotropinreleasing hormone $(\mathrm{GnRH})$ agonist and primed with $\mathrm{GnRH}$ antagonist. Fertil Steril. 2010;93:1668-75, http://dx.doi. org/10.1016/j.fertnstert.2008.12.047

12. Casper RF. Basic understanding of gonadotropin-releasing hormone-agonist triggering. Fertil Steril. 2015;103:867-9, http://dx.doi.org/10.1016/j.fertnstert.2014.12.129

13. Casper RF. Introduction: Gonadotropin-releasing hormone agonist triggering of final follicular maturation for in vitro fertilization. Fertil Steril. 2015;103:865-6, http://dx.doi.org/ 10.1016/j.fertnstert.2015.01.012

14. Engmann L, Benadiva C. GnRH agonist (buserelin) or HCG for ovulation induction in GnRH antagonist IVF/ICSI cycles: a prospective randomized study. Hum Reprod. 2005;20: 3258-60.

15. Babayof R, Margalioth EJ, Huleihel M, Amash A, ZylberHaran E, Gal M, et al. Serum inhibin A, VEGF and TNFalpha levels after triggering oocyte maturation with GnRH agonist compared with HCG in women with polycystic ovaries undergoing IVF treatment: a prospective randomized trial. Hum Reprod. 2006;21:1260-5.

16. Gülekli B, Göde F, Sertkaya Z, Işık AZ. Gonadotropin-releasing hormone agonist triggering is effective, even at a low dose, for final oocyte maturation in ART cycles: case series. J Turk Ger Gynecol Assoc. 2015;16:35-40, doi: 10.5152/jtgga.2015. 15084

17. Castillo JC, Dolz M, Bienvenido E, Abad L, Casañ EM, Bonilla-Musoles F. Cycles triggered with $\mathrm{GnRH}$ agonist: explor- 
ing low-dose HCG for luteal support. Reprod Biomed Online. 2010;20:175-81, http://dx.doi.org/10.1016/j.rbmo.2009.11.018

18. Pabuccu EG, Pabuccu R, Caglar GS, Y1lmaz B, Yarc1 A. Different gonadotropin releasing hormone agonist doses for the final oocyte maturation in high-responder patients undergoing in vitro fertilization/intra-cytoplasmic sperm injection. J Hum Reprod Sci. 2015;8:25-9, doi: 10.4103/0974-1208.153123

19. Papanikolaou EG, Humaidan P, Polyzos N, Kalantaridou S, Kol S, Benadiva C, et al. New algorithm for OHSS prevention. Reprod Biol Endocrinol. 2011;9:147-56, doi: 10.1186/14777827-9-147

20. Imbar T, Kol S, Lossos F, Bdolah Y, Hurwitz A, Haimov-Kochman R. Reproductive outcome of fresh or frozen-thawed embryo transfer is similar in high-risk patients for ovarian hyperstimulation syndrome using $\mathrm{GnRH}$ agonist for final oocyte maturation and intensive luteal support. Hum Reprod. 2012; 27:753-9, https://doi.org/10.1093/humrep/der463

21. Humaidan P, Polyzos NP, Alsbjerg B, Erb K, Mikkelsen AL, Elbaek $\mathrm{HO}$, et al. GnRHa trigger and individualized luteal phase hCG support according to ovarian response to stimulation: two prospective randomized controlled multi-centre studies in IVF patients. Hum Reprod. 2013;28:2511-21, doi: 10.1093/humrep/det249

22. Griesinger G, von Otte S, Schroer A, Ludwig AK, Diedrich K, Al-Hasani $\mathrm{S}$, et al. Elective cryopreservation of all pronuclear oocytes after $\mathrm{GnRH}$ agonist triggering of final oocyte maturation in patients at risk of developing OHSS: a prospective, observational proof-of-concept study. Hum Reprod. 2007;22: 1348-52.

23. Hernandez ER, Gomez-Palomares JL, Ricciarelli E. No room for cancellation, coasting, or ovarian hyperstimulation syndrome in oocyte donation cycles. Fertil Steril. 2009;91(4 Suppl): 1358-61, doi: 10.1016/j.fertnstert.2008.03.077

24. Orvieto R. Can we eliminate severe ovarian hyperstimulation syndrome? Hum Reprod. 2005;20:320-2, https://doi.org/ 10.1093/humrep/dei056

25. Humaidan P, Kol S, Papanikolaou EG. GnRH agonist for triggering of final oocyte maturation: time for a change of practice? Hum Reprod Update. 2011;17:510-24, doi: 10.1093/humupd/dmr008

26. Fatemi HM, Popovic-Todorovic B, Humaidan P, Kol S, Banker $\mathrm{M}$, Devroey $\mathrm{P}$, et al. Severe ovarian hyperstimulation syndrome after gonadotropin-releasing hormone $(\mathrm{GnRH})$ agonist trigger and "freeze-all" approach in GnRH antagonist protocol. Fertil Steril.2014;101:1008-11, doi:10.1016/j.fertnstert.2014.01.019

27. Gurbuz AS, Gode F, Ozcimen N, Isik AZ. Gonadotropin-releasing hormone agonist trigger and freeze-all strategy does not prevent severe ovarian hyperstimulation syndrome: a report of three cases. Reprod Biomed Online. 2014;29:541-4, doi: 10.1016/j.rbmo.2014.07.022

28. Fatemi HM, Garcia-Velasco J. Avoiding ovarian hyperstimulation syndrome with the use of gonadotropin-releasing hormone trigger. Fertil Steril. 2015;103:870-3, doi: 10.1016/j. fertnstert.2015.02.004
29. Youssef MA, Van der Veen F, Al-Inany HG, Mochtar MH, Griesinger G, Nagi Mohesen M, et al. Gonadotropin-releasing hormone agonist versus HCG for oocyte triggering in antagonist-assisted reproductive technology. Cochrane Database Syst Rev. 2014 Oct 31;10:CD00804, doi: 10.1002/14651858. CD008046

30. Yding Andersen C, Vilbour Andersen K. Improving the luteal phase after ovarian stimulation: reviewing new options. Reprod Biomed Online. 2014;28:552-9, doi: 10.1002/14651858. CD008046

31. Kol S, Humaidan P, Alsbjerg B, Engmann L, Benadiva C, García-Velasco JA, et al. The updated Cochrane Review 2014 on $\mathrm{GnRH}$ agonist trigger: repeating the same errors. Reprod Biomed Online. 2015;30:563-5, doi: 10.1016/j.rbmo.2015. 02.009

32. Engmann L, Benediva C. Agonist trigger: what is the best approach? Agonist trigger with aggressive luteal support. Fertil Steril. 2012;97:531-3, doi: 10.1016/j.fertnstert.2011.12.020

33. Humaidan P, Engmann L, Benadiva C. Luteal phase supplementation after gonadotropin-releasing hormone agonist trigger in fresh embryo transfer: the American versus European approaches. Fertil Steril. 2015;103:879-85, doi: 10.1016/j. fertnstert.2015.01.034

34. Orvieto R. A simplified universal approach to $\mathrm{COH}$ protocol for IVF: ultrashort flare GnRH-agonist/GnRH-antagonist protocol with tailored mode and timing of final follicular maturation. J Ovarian Res. 2015;8:69-76, doi: 10.1186/s13048015-0198-3

35. Castillo JC, Humaidan P, Bernabéu R. Pharmaceutical options for triggering of final oocyte maturation in ART. Biomed Res Int. 2014;2014:580171, http://dx.doi.org/10.1155/2014/58017

36. Al-Inany HG, Abou-Setta AM, Aboulghar M. Gonadotropinreleasing hormone antagonists for assisted conception. Cochrane Database Syst Rev. 2006;3:CD001750.

37. Al-Inany HG, Youssef MA, Aboulghar M, Broekmans F, Sterrenburg M, Smit J, et al. Gonadotropin-releasing hormone antagonists for assisted reproductive technology. Cochrane Database Syst Rev. 2011;5:CD001750, doi: 10.1002/14651858. CD001750

38. Gilliam ML. Gonadotropin-releasing hormone antagonists for assisted reproductive technology. Obstet Gynecol. 2011;118: 706-7, doi: 10.1097/AOG.0b013e31822bbbb2

39. Xiao JS, Su CM, Zeng XT. Comparisons of GnRH antagonist versus $\mathrm{GnRH}$ agonist protocol in supposed normal ovarian responders undergoing IVF: a systematic review and meta-analysis. PLoS One. 2014;9:e106854, http://dx.doi.org/10.1371/ journal.pone.0106854

40. Lin H, Li Y, Li L, Wang W, Yang D, Zhang Q. Is a GnRH antagonist protocol better in PCOS patients? A meta-analysis of RCTs. PLoS One. 2014;9:e91796, http://dx.doi.org/ 10.1371/journal.pone.0091796

41. Xiao J, Chen S, Zhang C, Chang S. Effectiveness of GnRH antagonist in the treatment of patients with polycystic ovary 
syndrome undergoing IVF: a systematic review and meta analysis. Gynecol Endocrinol. 2013;29:187-91, doi: 10.1016/j. fertnstert.2013.08.024

42. Gomez R, Gonzalez-Izquierdo M, Zimmermann RC, Novella-Maestre E, Alonso-Muriel I, Sanchez-Criado J, et al. Lowdose dopamine agonist administration blocks vascular endothelial growth factor (VEGF)-mediated vascular hyperpermeability without altering VEGF receptor 2-dependent luteal angiogenesis in a rat ovarian hyperstimulation model. Endocrinology. 2006:147:5400-11.

43. Gómez R, Soares SR, Busso C, Garcia-Velasco JA, Simón C, Pellicer A. Physiology and pathology of ovarian hyperstimulation syndrome. Semin Reprod Med. 2010;28:448-57, doi: 10.1055/s-0030-1265670

44. Ferrero H, García-Pascual CM, Delgado-Rosas F, Cauli O, Simón C, Gaytán F, et al. Dopamine receptor 2 activation inhibits ovarian vascular endothelial growth factor secretion in an ovarian hyperstimulation syndrome (OHSS) animal model: implications for treatment of OHSS with dopamine receptor 2 agonists. Fertil Steril. 2014;102:1468-76, doi: 10.1016/j.fertnstert.2014.07.1240

45. Soares SR. Etiology of OHSS and the use of dopamine agonists. Fertil Steril. 2012;97:517-22, doi: 10.1016/j.fertnstert. 2011.12.046

46. Kasum M, Orešković S. Treatment of ovarian hyperstimulation syndrome: new insights. Acta Clin Croat. 2010;49:421-7.

47. Tang H, Hunter T, Hu Y, Zhai SD, Sheng X, Hart RJ. Cabergoline for preventing ovarian hyperstimulation syndrome. Cochrane Database Syst Rev. 2012;2:CD008605, doi: 10.1002/ 14651858.CD008605

48. Leitao VM, Moroni RM, Seko LM, Nastri CO, Martins WP. Cabergoline for the prevention of ovarian hyperstimulation syndrome: systematic review and meta-analysis of randomized controlled trials. Fertil Steril. 2014;101:664-75, doi: 10.1016/j. fertnstert.2013.11.005

49. Youssef MA, van Vely M, Hassan MA, Al-Inany HG, Mochtar $\mathrm{M}$, Khattab S, et al. Can dopamine agonists reduce the incidence and severity of OHSS in IVF/ICSI treatment cycles? A systematic review and meta-analysis. Hum Reprod Update. 2010;16:459-66, doi: 10.1093/humupd/dmq006.

50. Alvarez C, Alonso-Muriel I, García G. Implantation is apparently unaffected by the dopamine agonist cabergoline when administered to prevent ovarian hyperstimulation syndrome in women undergoing assisted reproduction treatment: a pilot study. Hum Reprod. 2007;22:3210-4.
51. Busso C, Fernández-Sánchez M, García-Velasco JA, Landeras $\mathrm{J}$, Ballesteros A, Muñoz E, et al. The non-ergot derived dopamine agonist quinagolide in prevention of early ovarian hyperstimulation syndrome in IVF patients: a randomized, doubleblind, placebo-controlled trial. Hum Reprod. 2010;25:9951004, doi: 10.1093/humrep/deq005

52. Sherwal V, Malik S, Bhatia V. Effect of bromocriptine on the severity of ovarian hyperstimulation syndrome and outcome in high responders undergoing assisted reproduction. J Hum Reprod Sci. 2010;3:85-90, doi: 10.4103/0974-1208.69342

53. Baumgarten M, Polanski L, Campbell B, Raine-Fenning N. Do dopamine agonists prevent or reduce the severity ovarian hyperstimulation syndrome in women undergoing assisted reproduction? A systematic review and meta-analysis. Hum Fertil (Camb). 2013;16:168-74, doi: 10.3109/14647273.2013. 833348

54. Naredi N, Talwar P, Sandeep K. VEGF antagonist for the prevention of ovarian hyperstimulation syndrome: current status. Med J Armed Forces India. 2014;70:58-63.

55. Zarek SM, Muasher SJ. Mild/minimal stimulation for in vitro fertilization: an old idea that needs to be revisited. Fertil Steril. 2011;95:2449-55, doi: 10.1016/j.fertnstert.2011.04.041

56. Rinaldi L, Lisi F, Selman H. Mild/minimal stimulation protocol for ovarian stimulation of patients at high risk of developing ovarian hyperstimulation syndrome. J Endocrinol Invest. 2014;37:65-70, doi: 10.1007/s40618-013-0021-1

57. Casano S, Guidetti D, Patriarca A, Gennarelli G, Revelli A. Mild ovarian stimulation with GnRH-antagonist vs. long protocol with low dose FSH for non-PCO high responders undergoing IVF: a prospective, randomized study including thawing cycles. J Assist Reprod Genet. 2012;29:1343-51, doi: 10.1007/ s10815-012-9863-2

58. Gibreel A, Maheshwari A, Bhattacharya S. Clomiphene citrate in combination with gonadotropins for controlled ovarian stimulation in women undergoing in vitro fertilization. $\mathrm{Co}_{-}$ chrane Database Syst Rev. 2012;11:CD008528, doi: 10.1002/ 14651858.CD008528

59. Figueiredo JB, Nastri CO, Vieira AD, Martins WP. Clomiphene combined with gonadotropins and $\mathrm{GnRH}$ antagonist versus conventional controlled ovarian hyperstimulation without clomiphene in women undergoing assisted reproductive techniques: systematic review and meta-analysis. Arch Gynecol Obstet. 2013;287:779-90, doi: 10.1007/s00404-0122672-0 


\section{Sažetak}

\section{MEDIKAMENTNA PREVENCIJA SINDROMA HIPERSTIMULACIJE JAJNIKA}

\section{Kasum, S. Orešković, D. Franulić, E. Čehic, A. Lila, G. Vujić i F. Grgić}

Svrha ovoga rada bila je analizirati današnje medikamentne strategije u prevenciji sindroma hiperstimulacije jajnika za vrijeme stimulacije ovulacije u postupku izvantjelesne oplodnje. Zahvaljujući suvremenim metodama prevencije pojavnost sindroma hiperstimulacije se kreće od $0,18 \%$ do $1,40 \%$. Premda se nijedna prevencijska strategija nije pokazala u potpunosti djelotvornom, postoje čvrsti dokazi da zamjena humanog korionskog gonadotropina gonadotropnim otpuštajućim hormonom nakon antagonista gonadotropnog otpuštajućeg hormona te umjereni dokazi da protokoli antagonista gonadotropnog otpuštajućeg hormona, agonisti dopamina i blagi protokoli smanjuju pojavnost sindroma hiperstimulacije. Između nekoliko agonista gonadotropnog otpuštajućeg hormona najčešce se koriste buserelin $0,5 \mathrm{mg}$, triptorelin $0,2 \mathrm{mg}$ i leuprolid (0,5-4 mg). Premda se danas smatra da je gonadotropni otpuštajući hormon najuspješniji u prevenciji sindroma hiperstimulacije jajnika, zbog rane luteolize potrebna je intenzivna potpora žutom tijelu primjenom estradiola i progesterona ili sniženim dozama humanog korionskog gonadotropina na dan aspiracije jajnih stanica da bi se postigle optimalne stope zanošenja. Između danas dostupnih agonista dopamina kabergolin, kinagolid i bromokriptin su lijekovi koji se najčešće primjenjuju i koje bi trebalo primjenjivati u prevenciji ranog i kasnog oblika sindroma hiperstimulacije. Blagi stimulacijski protokoli predstavljaju privlačan izbor u prevenciji sindroma hiperstimulacije sa zadovoljavajućim stopama trudnoće.

Ključne riječi: Sindrom hiperstimulacije jajnika-prevencija i kontrola 